\title{
Coal Facies Characteristics and Coal Formation Mechanism of No. 38 Coal Seam in Cuipingshan Coal Mine
}

\author{
Fumei Xu* , Lin Jiang, Daoliang Bao \\ School of Resource Engineering, Longyan University, Longyan, China \\ Email address: \\ xfm126@126.com (Fumei Xu), ly_university@163.com (Lin Jiang), 1499236080@qq.com (Daoliang Bao) \\ *Corresponding author
}

\section{To cite this article:}

Fumei Xu, Lin Jiang, Daoliang Bao. Coal Facies Characteristics and Coal Formation Mechanism of No. 38 Coal Seam in Cuipingshan Coal Mine. International Journal of Economy, Energy and Environment. Vol. 3, No. 5, 2018, pp. 45-50. doi: 10.11648/j.ijeee.20180305.12

Received: October 23, 2018; Accepted: December 3, 2018; Published: December 6, 2018

\begin{abstract}
No. 38 coal seam is the main coal seam in Cuipingshan Coal Mine. In order to reveal its coal-forming mechanism, the microlithologic types of No. 38 coal seam in Cuipingshan Coal Mine are analyzed by using modern testing methods such as sequence stratigraphy, coal petrology and geochemistry. We find that the maceral of No. 38 coal seam is mainly vitrinite, the average content is respectively $57.28 \%$, the vitrinite is mainly telinite and desmocollinite, and the microlithotypes is semi-bright coal. The coal facies of the No. 38 coal seam include tidal flat-tidal channel wet forest swamp facies, shoreland lacustrine wet forest swamp facies and barrier island-lagoon low swamp facies. The formation background of coal seam is an environment of shoreland lacustrine facies, barrier island lagoonfacies and tidal flat-tidal channel swamp facies, etc., which are sea-land transitional facies. The shoreland lacustrine wet forest swamp facies and barrier island-lagoon low swamp facies are the main coal facies types of the No. 38 coal facies in the region of interest and are distributed throughout the whole coal seam section. This indicates that it always predominated in the evolutionary process of swamp. The tidal flat-tidal channel wet forest swamp facies also accounted for a certain proportion in the formation process of coal seam, and constitutes periodic cycle structure with the shoreland lacustrine wet forest swamp facies and barrier island-lagoon low swamp facies. Generally the coal formation mechanism of No. 38 coal seam is a regressive swamp development process, and its coal formation environment is tidal flat-tidal channel swamp and shoreland lacustrine swamp. Besides, the development process of peat swamp is influenced by the frequent advance and retreat of secondary seawater.
\end{abstract}

Keywords: Coal Facies Characteristics, Coal Formation Mechanism, Peat Swamp, Evolutionary Pattern, Cuipingshan Coal Mine

\section{Introduction}

The term coal facies refers to the primary genetic types of coal, which are dependent on the milieu under which the peats originate. The facies of a coal expresses itself through the maceral and mineral contents of the coal, through certain of its chemical properties, which are largely independent of rank, for example, the sulphur and nitrogen contents and the $\mathrm{H} / \mathrm{C}$ ratio of the vitrinite, and also through certain textural properties. The research on the coal facies is of far reaching importance for restoring the material conditions and sedimentary environment of coal formation. The sedimentary environment and coalforming action type of coal-bearing formation can be determined via research on the organic microscopic composition, lithotype and the characteristics of coal seam and its surrounding rock's precipitation facies. Besides, the research on macroscopic coal rock and microscopic coal rock, especially on the coal facies characteristics of coal seam, can be used to judge its swamp types and infer its swamp evolutionary pattern. Years of efforts at the research on the coal facies have produced tremendous research results, which mainly include discriminating the sedimentary environment via coal facies parameters [1-2], restoring paleosalinityin aqueous medium [3-4], hydrodynamic conditions [5] and coalforming plant types [6], etc. A great many scholars also delved into the coal rock characteristics of Permian coal-bearing rock series in southwest Fujian and achieved certain research results [7]. Based on the previous research, the paper takes the No. 38 
coal seam in Cuipingshan coal mine in Longyong coalfield in southwest Fujian for example to analyze its coal rock characteristics and coal facies types by combining coal petrology and sedimentary geochemistry, in an attempt to obtain a relatively comprehensive knowledge about its coal facies type and ancient peat swamp evolution, thereby providing theoretical references for looking for the coal-rich area. In an effort to further research the coal petrologic characteristics and coal formation environment evolution of the coal seam, the systematic sampling and related tests were conducted emphatically on the No. 38 coal seam.

\section{Geological Background of the Studying Area}

Lying in the east urban area in Xinluo district, Longyan, Fujian, the Cuipingshan coal mine is part of the Longyong coalfield. The Caledonian movement integrated the terrane of northwest Fujian, terrane of southwest Fujian and terrane of east Fujian to form the Wuyi-Yunkai Island Arc Fold System and the Zhenghe-Dabusubduction zone and Sanming-Shanghai remnant arc and back-arc basin. Longyan Basin was formed between Sanming-Shanghai remnant arc and Daiyun mountain arc. In the Hercynian period, the above two basins evolved into a depression basin in southwest Fujian Province [8]. The coal accumulating basin of Longyong coalfield was just formed in this depression basin. The major coal bearing strata of this mining field are the No.1 and No.3 Member of Tongziyan Formation of Middle Permian. The No.1 Member stratum is sea and land interaction sediments, and contains three minable seams. The No. 38 Member stratum is marine sediment excluding coal and contains a great many animals and plants fossils.

The No. 3 Member is a set of coal-bearing sedimentary strata mainly based on shoreland lacustrine facies and containing six workable seams. Wherein, the No. 38 coal seam is the coal seam with average thickness of $2.13 \mathrm{~m}$ and simple structure, the whole area is stable and has the largest economic significance. The seam roof of this area is the mudstone, and contains rich animal fossils (Pygmochonetesjingxianensis, Lingula, and Gastropod, etc.) metasomatized by the pyrite. The swamp environment is significantly influenced by the seawater and mingled with many big iron and earth nodules. The floor is sandy mudstone withmany pyrite crystals on the upper layer.

\section{Research Technique and Experimental Result}

The No. 38 coal seam was sampled from the floor to the roof according to the macroscopic lithotypes in the cross-hole of Cuipingshan coal mine, and was divided into eight natural layers. The collection of samples was strictly conducted as per the sampling specifications in GB482-2008. According to the national standard GB474-2008 of the Method for Preparation of Coal Sample, the coal seam sample of each layer was smashed until it could pass $1.0 \mathrm{~mm}$ griddle to prepare polished grain mount. The remaining samples were smashed to $0.1 \mathrm{~mm}$ and divided into four classes, to be subjected to technical analysis, maceral mensuration, elemental analysis, sulfur content analysis and ash composition analysis.

Classification scheme of bituminous coal macerals is based on international society of coal and rock (ICCP, 1976) and the international organization for Standardization standard ISO/DIS7404/3.In accordance with relevant national standards, industrial analysis, elemental analysis, total sulfur analysis and sulfur content determination of coal samples were carried out. Neutron activation method was used to determine the contents of elements in stratified coal samples and coal ash samples.

According to the measured data of coal rock's macerals, the method established by Diessel [9] was used to calculate the tissue preserving index of coal seam sample of each layer (TPI, $\mathrm{TPI}=($ telinite + homocollinite + fusinite + semifusinite $) /($ desmoc ollinite + macrinite + inertodetrinite) $)$ and gelification index $($ GI, GI $=$ (vitrinite + macrinite $) /($ fusinite + semifusinite + inertodetrinite), which could be used to distinguish the ancient peat swamp types and coal facies types of each coal layer.

The ratio of vitrinite to inertinite (the vitrinite (V) represents a wet reducing environment, the inertinite (I) represents a dry oxidation environment) was adopted to reflect the swamp's water overlaying degree and the wetting-drying condition of climate.

The ground water impact index (GWI) and vegetation index (VI) were adopted to reflect the underground water level and vegetation type.

The correlation of the ash content productivity with the four parameters of V/I, TPI, GI, organic sulfur content is used to reflect the chemical properties and hydrodynamic conditions of aqueous medium.

The test data of samples and the calculation result of related indices are as shown in table 1 .

Table 1. Analysis data about the basic coal quality in No. 38 coal seam in Cuipingshan coal mine.

\begin{tabular}{|c|c|c|c|c|c|c|c|c|c|c|c|c|}
\hline \multirow{2}{*}{$\begin{array}{l}\text { layer } \\
\text { samples }\end{array}$} & \multirow{2}{*}{$\begin{array}{l}\text { Thick- } \\
\text { Ness }\end{array}$} & \multirow{2}{*}{ Rock type } & \multicolumn{2}{|c|}{ Technical analysis } & \multicolumn{2}{|c|}{ Maceral (\%) } & \multicolumn{4}{|c|}{ Maceral ratio } & \multicolumn{2}{|c|}{ Sulfur content $(\%)$} \\
\hline & & & $\mathbf{M}_{\mathrm{ad}}$ & $\mathbf{A}_{\mathrm{ad}}$ & $\mathbf{V}$ & I & $\mathbf{M}$ & TPI & GI & VI & $\mathbf{S}_{\mathrm{t}, \mathrm{d}}$ & $\mathbf{S}_{\mathbf{O}, \mathrm{d}}$ \\
\hline roof & 49 & fine siltstone & - & - & - & - & - & - & - & - & 0.55 & 0.66 \\
\hline 1 & 29 & Semidull coal & 4.0 & 8.5 & 52.3 & 38.5 & 8.4 & 1.28 & 3.29 & 1.33 & 0.73 & 0.44 \\
\hline 2 & 33 & brighter coal & 4.6 & 8.2 & 49.6 & 40.1 & 6.6 & 1.65 & 2.04 & 1.26 & 0.65 & 0.51 \\
\hline 3 & 19 & Semidull coal & 6.1 & 9.6 & 48.0 & 41.6 & 7.4 & 1.17 & 2.32 & 1.17 & 0.64 & 0.43 \\
\hline 5 & 42 & brighter coal & 5.3 & 7.4 & 78.3 & 16.2 & 6.7 & 0.85 & 5.07 & 4.73 & 1.94 & 0.67 \\
\hline
\end{tabular}




\begin{tabular}{|c|c|c|c|c|c|c|c|c|c|c|c|c|}
\hline \multirow{2}{*}{$\begin{array}{l}\text { layer } \\
\text { samples }\end{array}$} & \multirow{2}{*}{$\begin{array}{l}\text { Thick- } \\
\text { Ness }\end{array}$} & \multirow{2}{*}{ Rock type } & \multicolumn{2}{|c|}{ Technical analysis } & \multicolumn{2}{|c|}{ Maceral (\%) } & \multicolumn{4}{|c|}{ Maceral ratio } & \multicolumn{2}{|c|}{ Sulfur content (\%) } \\
\hline & & & $\mathbf{M}_{\mathbf{a d}}$ & $\mathbf{A}_{\text {ad }}$ & $\mathbf{V}$ & $\mathbf{I}$ & $\mathbf{M}$ & TPI & GI & VI & $\mathbf{S}_{\mathrm{t}, \mathrm{d}}$ & $\mathbf{S}_{\mathbf{o}, \mathrm{d}}$ \\
\hline 6 & 32 & mudstone & - & - & - & - & - & - & - & - & 1.72 . & 1.23 \\
\hline 7 & 38 & semibright coal & 4.7 & 8.3 & 51.8 & 41.4 & 9.3 & 1.35 & 2.66 & 1.27 & 0.83 & 0.60 \\
\hline 8 & 25 & brighter coal & 4.3 & 7.2 & 56.6 & 37.7 & 7.2 & 1.26 & 3.28 & 1.47 & 0.92 & 0.62 \\
\hline 9 & 35 & Semidull coal & 4.7 & 8.9 & 53.1 & 32.6 & 7.6 & 0.92 & 4.13 & 1.66 & 1.05 & 0.58 \\
\hline floor & 147 & Coarse siltstone & - & - & - & - & - & - & - & - & 0.62 & 0.43 \\
\hline
\end{tabular}

Note: Mad-inherent moisture content, air dried basis; Aad-ash content productivity, air dried basis; V-vitrinite; I-inertinite; M-mineral; TPI-plant structure preserve index; GI-gelatinization index; St,d-total sulfur; dry basis; So,d-organic sulfur; dry basis.

The content of exinite is very small with only a fraction of elliptic oxyresinite. So it is not included in the statistics.

\section{Genetic mark of Coal Facies and Coal Facies Types}

\subsection{Coal Petrological Mark}

The coal petrology marks are among the most immediate and reliable distinctions reflecting the origin of coal seam. They include coal rock components, assemblage mark and the structure of coal seam--structural feature [10]. The macroscopic lithotypes for No. 38 coal are mainly bright coal and semi-bright coal based, with little dull coal and specular coal. In vertical sequence, the bright coal, semi-bright coal, semidull coal and specularalternate with each other with different widths of stripe.

The observation under a microscope showed that the bright coal stripe is mainly composed of homogeneous pattern vitrinite or telinite. The bright coal stripe is mainly composed of telinite. The dull coal strip is mainly composed of inertinite.

The No. 38 coal seam in the region of interest is rich in vitrinite whose average content is about $59.42 \%$. The quantitative statistical result of maceral showed that the vitrinite of this coal seam is mainly telinite and desmocollinite, while the average content of inertinite is mainly macrinite and semifusiniteis. According to different constructions of macerals, the construction type of microstructure of No. $38 \mathrm{coal}$ seam is: banded structure-parallel structure, lenticular structure-parallel layered structure. In a word, each coal maceral contained in the coal seam and its content are important marks for the research on the origin of coal seam, and also are the evidence for differentiation of the patterns of coal seam origin in this paper [11].

Analysis shows that the bright coal dominate the middle part of coal seam, and the proportion of dull coal and semidull coal in the neighborhood of top and bottom boundaries significantly rises, which reflects that the degree of water overlaying in the middle part of coal seam is obviously higher. The macroscopic coal rock composition also has similar characteristics, yet the microscopic characteristics of coal seam shows several small fluctuations, which indicates that the secondary fluctuation of water overlaying conditions existed in the coal formation process.

\subsection{Sedimentological Mark}

The Tongziyan Formation is sedimentary clastic littoral zone, and its sedimentary characteristics are generally impacted by the pulsations of transgressive and regressive seawater, which causes the sedimentary characteristics and coal accumulation to both show dramatic differences and take on regular alternative changes. The sedimentary system of this littoral zone can be divided into barrier island - lagoon sedimentary assemblage, tidal flat-tidal channel sedimentary combination and shoreland lacustrine sedimentary assemblage.

The direct roof of No. 38 coal seam is mudstone and rich in plant fossils such as Compsopteris, Pecopteris, and is also rich in iron and siliceous nodules. The direct bottom is sandy mudstone and contains many iron nodules. The stratum of rhythmic litho facies assemblage is constituted by the grey black sandy mudstone, black mudstone and grey fine stone. The grain size of sediment also shows rhythmic changes, which reflects the characteristics of assemblage of barrier island-lagoon facies, tidal flat-tidal channel facies and shoreland lacustrine facies.

\subsection{Mineralogical Mark}

The mineral content in No. 38 coal is generally below $10 \%$. The examination under the microscope showed that the common mineral in the coal is clay mineral, the pyrite and siderite. The sulfate minerals only appear in some layers.

The ash content productivity of each layer of No. 38 coal seam has a correlation with the four parameters of V/I, TPI, GI, organic sulfur content, which can reflect the chemical properties and hydrodynamic conditions of aqueous medium to a certain extent.

In the development process of swamp, with the accumulation of sediment, the hydrodynamic conditions were weakened, and the water mass became relatively closed, leading to the increase of reducibility, which caused the sedimentation in swamp water to decrease. Then the ash content in the coal quality was reduced. Such swamp environment worsened the vegetation texture preserving degree, and deepened the gelification degree of plant remains. This condition also resulted in the increase of sulfur content in the coal quality. In the meanwhile, the vitrinite content increased in the coal, leading to the increase of V/I ratio. In contrast, the stronger dynamic conditions of aqueous medium led to stronger oxidation of swamp environment and higher 
ash content in coal quality. Thus, to take Ad, V/I, TPI, GI, and organic sulfur (So), etc. as the analytical parameters for dynamic conditions of swamp water medium is of important significance. The Figure 1 shows that the ash content
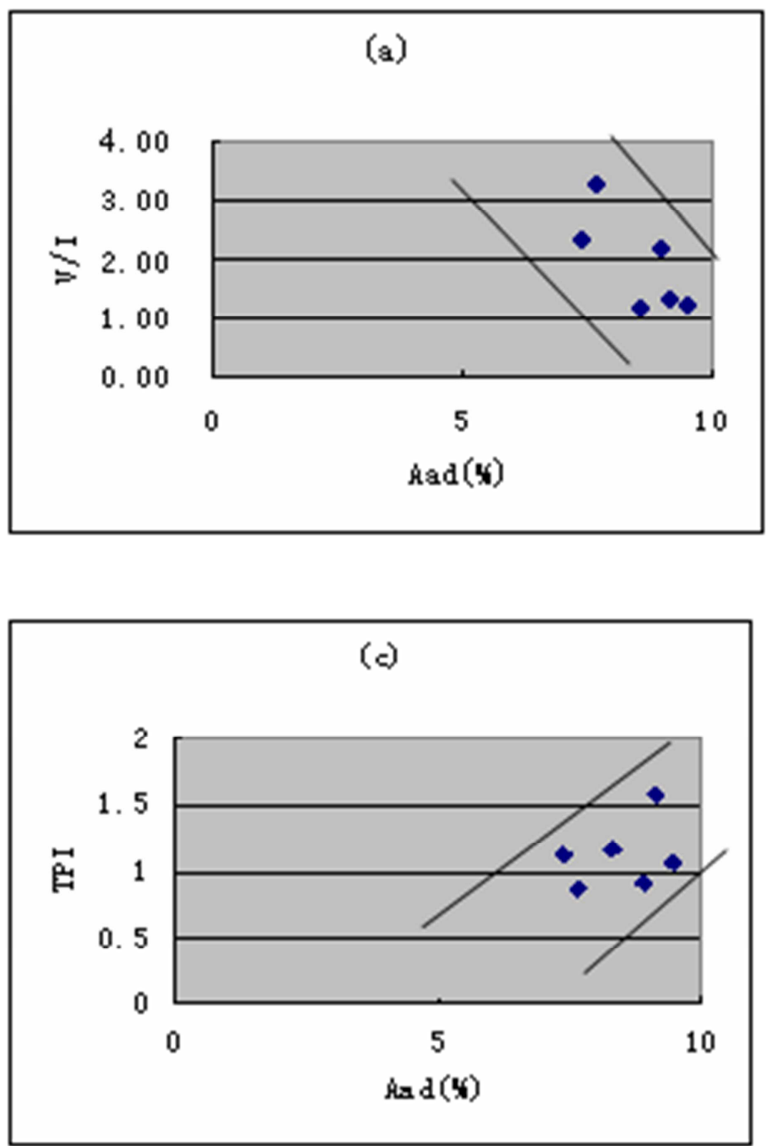

Figure 1. Plots of ash yield to relative parameters ofNo. 38 coal seam from the Cuipingshancoal mine.

It is observed from table 1 that $\mathrm{St}$, $\mathrm{d}$ has a positive correlation with GI, V, and has a negative correlation with TPI. The GI and V show a change trend from small-big-small, while TPI case is contrary, which indicates that the water overlaying depth of swamp in the formation process of the No. 38 coal seam was from shallow-deep-shallow, while the corresponding hydrodynamic conditions became from week-strong-weak. This is consistent with the swamp sedimentation experienced by the No. 38 coal, showing that the sulfur content and water overlaying degree in coal seam are related to the influence of seawater, and the vertical change trend of total sulfur content in the coal is significantly controlled by the swamp environment.

\subsection{Coal Facies Types and Their Characteristics}

According to the GI-TPI diagram established by Diessel and with ground water impact index (GWI) and vegetation index (VI) as reference, the No. 38 coal seam is divided into three coal facies types of wet forest swamp I, wet forest swamp II and low swamp. The three coal facies types respectively develop littoral tidal flat - tidal channel and barrier island- lagoon depositional environment, thereby productivity of each stratification of No. 38 coal seam has a negative correlation with the three parameters of V/I, GI, So, and has a positive correlation with TPI.
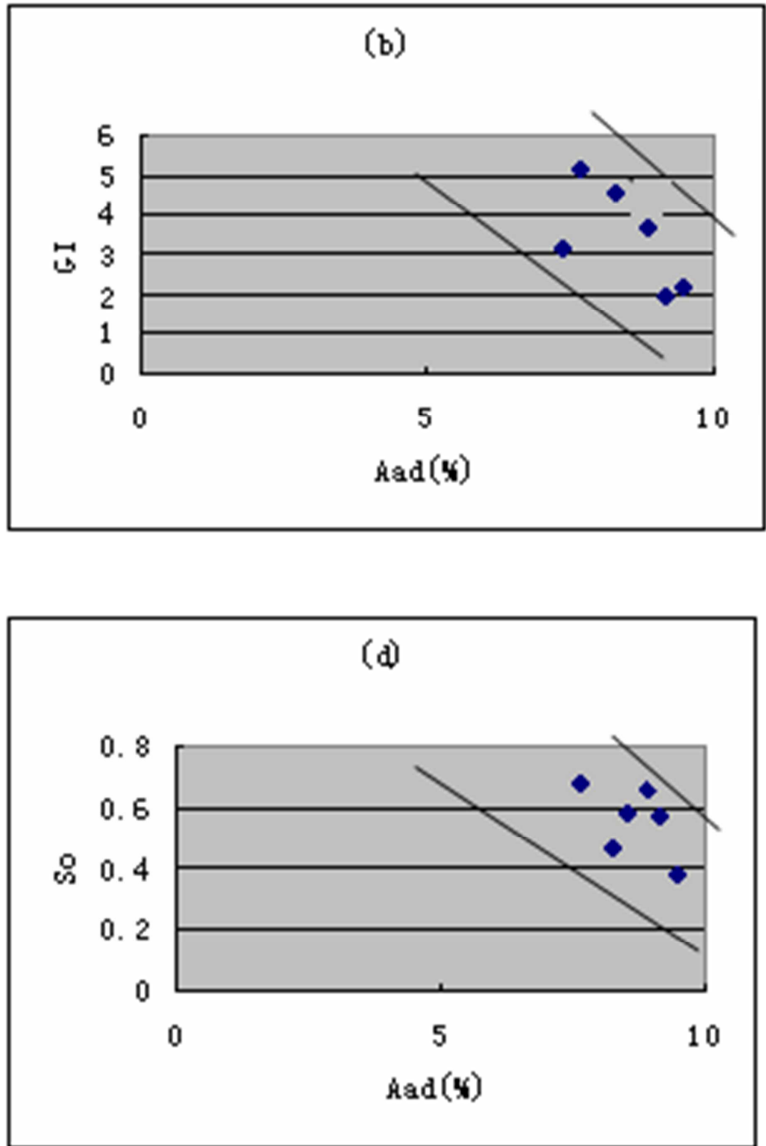

constituting three basic coal facies types, i.e. tidal flat-tidal channel wet forest swamp facies (A), shoreland lacustrine wet forest swamp facies (B) and barrier island-lagoon low swamp facies (C). (Figure 2)

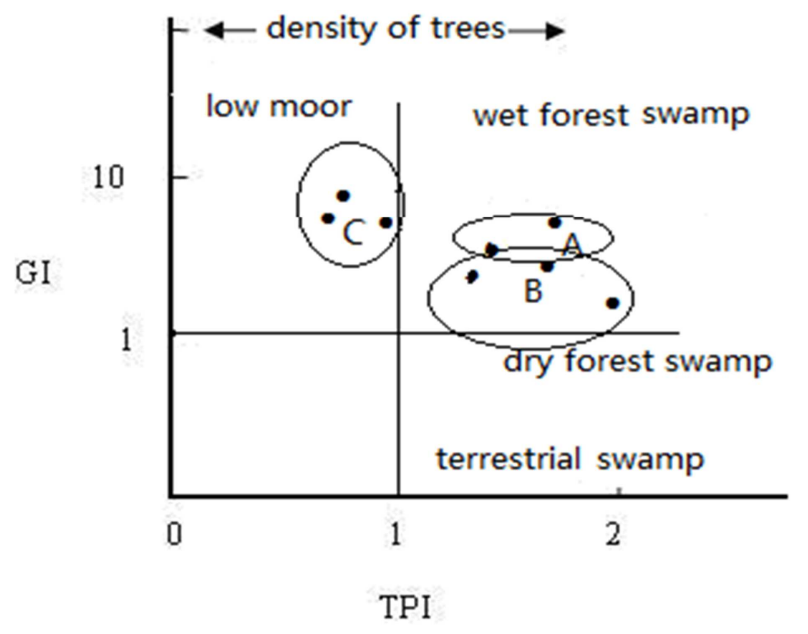

Figure 2. Facies type of No. 38 coal seam from the Cuipingshancoal mine.

(1) Tidal flat-tidal channel wet forest swamp facies (A) 
Under the tidal action, the tidal channel sand body of side product type serves as the framework, which is surrounded by the tidal flat sediments to constitute the sedimentary pattern of side product-filling depositional model. This belongs to the product of intertidal zone, and the structure types of sedimentation are rich. The organic constituents are mainly vitrinite and inertinite, and the GI and TPI values are high.

(2) Shoreland lacustrine wet forest swamp facies (B)

The shoreland lacustrine swamp facies and barrier island-lagoon swamp facies are closely related from the vertical to the plane, being the result of high dilution or closing lagoon of the barrier island. The macerals are dominated by the vitrinite, and GI value is high, while TPI value is low.

(3) Barrier island-lagoon low swamp facies (C)

Due to regression, the lagoonal sediment covers the original barrier island sand body. In the progradation of coastline, the swamp environment endlessly advanced seaward, forming a closed brackish water swamp environment, in which, the pyrite content and vitrinite content are high, so do the values of GI and TPI.

In the whole evolutionary process of swamp, the shoreland lacustrine swamp facies and barrier island-lagoon swamp facies were the main body of coal facies types of the No. 38 coal seam in the region of interest, and are distributed throughout the whole coal seam section. This indicates that it always predominates in the evolution process of swamp. The tidal flat-tidal channel swamp facies appears more in the upper and lower part of coal seam, alternates with shoreland lacustrine swamp facies and barrier island-lagoon swamp facies, and show a periodic cycle structure. This indicates that the No. 38 coal seam was formed in relatively humid coal forming environment and climate.

\section{Coal Forming Mechanism}

The sedimentological analysis on the adjoining rock of No. 38 coal and the whole coal-bearing formation reveals that its formation background was littoral, barrier island lagoon, tidal flat sedimentary environment of transition zone. This assemblage of sedimentary environments reflects that the peat sedimentation process was both influenced by the seawater and river water, which phenomenon is evidenced by the macerals of No. 38 coal seam.

Different paleogeographical and paleoclimatic environment lead to different combination characteristics of vegetations. The analysis on the plant residual in the coal reveals the combination relation of vegetation types in the coal formation process. The coal forming plants of No. 38 coal are mainly Cordaitopsida and Pteridospermopsida. Filicopsida and Cycadopsida are also commonly seen, which reflects that the coalforming swamp environment was wet. The presence of Cordaitopsida plants reflects that the swamp water medium is semi saline water.

Via the above analysis and based on the coal petrological characteristics, sedimentological characteristics and mineralogical characteristics, swamp hydrodynamic force and fossil plant characteristics, the evolutionary pattern of peat swamp for the No. 38 coal seam in Tongziyan formation in Cuipingshan coal mine is abstracted as followes:

(1) The development of peat swamp for the No. 38 coal seam is generally a regressive process and significantly co-influenced by the sea water and river water. Due to uplift of sedimentary topography, clastic littoral zone sediments appeared. This led to shrinking of sea area. At the bay mouth, as the wave action is the main controlling factor, the parallel shoreline developed the long barrier island; while in the depth of bay, the tidal action is the main controlling factor, hence development of tidal flat-tidal channel sedimentation. Due to further regression, lake swamp environment dominates, except that a minority of regions are connected with the sea water.

The mudstone in seam roof contains rich plant fossils such as Compsopteris and Pecopteris. The direct bottom is sandy mudstone and contains many iron nodules. The rhythmic litho facies combination is constituted by the grey black sandy mudstone, black mudstone and grey pack sand. Such grain size of sediments also shows rhythmic variations, which reflects the characteristics of assemblage of barrier island-lagoon facies, tidal flat-tidal channel facies and shoreland lacustrine facies. Thereby explicitly indicated that No. 38 coal seam was co-influenced by the seawater and river water in its formation process.

(2) The No. 38 coal seam is frequently influenced by the secondary transgression and regression in the development process of peat swamp. In the lower part of the coal seam (the eighth stratification to the seventh stratification), the peat swamp is the semi saline-water environment with relatively stronger reducibility of aqueous medium and relatively weaker hydrodynamic force, resulting in relatively higher content of vitreous coal components, gelated components and organic sulfur and relatively lower mineral content.

In mid-lower part (the sixth stratification) of coal seam, the peat swamp is mainly the fresh water-semisaline water environment with weaker reducibility of aqueous medium and relatively stronger hydrodynamic force, resulting in relatively more inertinite components and minerals and relatively lower content of gelated components and organic sulfur. In the middle part of coal seam (the fifth stratification to the fourth stratification), the peat swamp is mainly the salt water environment with strong reducibility of aqueous medium and weak hydrodynamic force, resulting in high content of vitreous coal components, gelated components and organic sulfur.

In mid-upper part (the third stratification to the second stratification) of coal seam, the peat swamp is again changed into the fresh water - semi saline water environment, resulting in relatively more inertinite components and minerals and relatively lower content of gelificated components and organic sulfur. In the upper part of coal seam (the first stratification), the peat swamp is again changed into the semi saline-water environment, resulting in relatively higher content of vitreous coal components, gelificated components and organic sulfur, 
and lower mineral content.

\section{Conclusion}

The main conclusion of the paper is:

(1) The macroscopic litho types of No. 38 coal seam is mainly semi-bright coal. The macerals are rich in vitrinite. The average content is respectively $57.28 \%$. The vitrinite is mainly telinite and desmocollinite.

(2) St,d is in a positive correlation with GI, V, and is in a negative correlation with TPI. The GI and V change from small-big-small, while the TPI case is in contrast, indicating that the water overlaying depth of swamp became from shallow-deep-shallow in the formation process of No. 38 coal seam, and the corresponding hydrodynamic force became from weak-strong-weak again.

(3) The coal facies of the No. 38 coal seam include tidal flat-tidal channel wet forest swamp facies, shoreland lacustrine wet forest swamp facies and barrier island-lagoon low swamp facies. The formation background of coal seam is an environment of shoreland lacustrine facies, barrier island lagoonfacies and tidal flat-tidal channel swamp facies, etc., which are sea-land transitional facies. The shoreland lacustrine wet forest swamp facies and barrier island-lagoon low swamp facies are the main coal facies types of the No. 38 coal facies in the region of interest and are distributed throughout the whole coal seam section. This indicates that it always predominated in the evolutionary process of swamp. The tidal flat-tidal channel wet forest swamp facies also accounted for a certain proportion in the formation process of coal seam, and constituted periodic cycle structure with the shoreland lacustrine wet forest swamp facies and barrier island-lagoon low swamp facies.

(4) Generally the development of peat swamp for the No. 38 coal seam is a regressive process, and is under a joint influence of the seawater and river water. However, the development process of peat swamp was influenced by the frequent advance and retreat of secondary seawater.

\section{Acknowledgements}

This project was supported by the National Natural Science Foundation of Fujian Province, China (No.2015J01170).

\section{References}

[1] Zhou QY, Shao LY, Chen ZX, et al, 2016 Depositional environments and coal-accumulation characteristics of the Upper Triassic Xujiahe Formation in the northern segment of Huaying Mountain, Sichuan Basi Journal of China Coal Society 3 703-711.

[2] Hou X X, Tang Y G, Son X X, et al, 2013 Coal petrology and coal facies of Zhongliangshan mining area, Chongqing Coal Geology \& Exploration 56 - 10.

[3] Lu J, Shao L Y, Yang M F, et al, 2014 Coal facies evolution, sequence stratigraphy and palaeoenvironment of swamp in terrestrial basin Journal of China Coal Society12 2473-2481.

[4] Dai S F, Zhou Y P, Ren D Y, et al, 2007 Late permian coal geochemistry and mineralogy characteristic and origin in Songzao coalfield of Chongqing Science in China (Series D: Earth Sci2ences)3 353 - 362.

[5] Li J, Zhuang X G, Zhou J B, He YL, 2012 Coal facies characteristic and identification of transgressive/regressive coal-bearing cycles in a thick coal seam of Xishanyao formation in eastern junggar coal field, Xinjiang Journal of Jilin Unviersity:Earth Science Edition 2 104-114.

[6] Wang Y, Li L Q, Zhang X Q 2016 Inertinite of Coal-Rocks and Its Application to the Paleoenvironment Reconstruction of Peat and M ire Geological Revie2 375 - 380.

[7] Wu C Q 1984 Research on Longyong coal seam deformation characteristics and deformational factors Coal Geology \& Exploration 634 - 35.

[8] Wei D G, Jie Y J, Huang T G, 1997 Regional geological structure of fujianRegional geology of china 2 162-170.

[9] Diessel C F K 1986 On the correlation between coal facies and depositional environment Advances in the Study of the Sydney Basin, Proceedings of 20th Symposium of University of Newcastle 19-22.

[10] Moore T A, Stanton R W, et, al, 1990 Maceral and Palynomorphfacies from two Tertiary peat-forming enviroments in the Powder River Basin, U.S.A Int. J. Coal Geo. $15293-316$.

[11] Stach, E, Mackowsky. M. TH., Teichmuller. M., Taylor. G. H, Chandra. D, Techmuller. R 1982 Stach's text book of Coal Petrology, GenruderBorntraeger, Germany. 